\title{
EUROPEAN EXPERIENCE OF LAND RESOURCE POTENTIAL DEVELOPMENT IN THE CONDITIONS OF GLOBALIZATION
}

Chumachenko A., PhD in Economics

E-mail: anchumachenko@ukr.net

National University of Life and Environmental Sciences of Ukraine

Kryvoviaz Y., PhD in Economics

E-mail: zmenichka@ukr.net

National University of Life and Environmental Sciences of Ukraine

Zhuk O.,PhD in Economics

E-mail:oleksiy_zhuk@ukr.net

National University of Life and Environmental Sciences of Ukraine

The article analyzes the use of land resources of countries in the context of globalization. Investment-attractive regions have been identified, the socio-economic and political conditions of which contribute to the seizure of land by foreign investors. Sources of food security of countries with developed economies are substantiated. Peculiarities of formation of land and resource space of European neo-colonial countries are determined. One of the most important historical events in the political and socio-economic dimensions of the world was colonialism, associated with the development of capitalism. In the book, Eric Wolfe, "Europe and People Without History", describes in detail the global expansion of the borders of European states in order to control both human and natural resources, as well as to expand global development and promote Christianity [1]. European colonialism became an early form of globalization that shaped most of the world's current political borders. In this way, technologies, food and ideas based on the colonial countries - Britain, Spain, France, Portugal and the Netherlands, etc. were transported. The main goal is to use the limited resources of the colony country and make a profit. This approach is called neocolonialism (corporate colonialism), just as classical European colonialism aims at the comprehensive exploitation of natural resources, labor, and markets for superprofits. 
Key words: territory, land use, land acquisition, food security, agricultural land, land.

Formulation of the problem. With Ukraine's choice of the European vector of integration, research on the peculiarities of land use in the countries of the European Union has become much more relevant. Equally important is the study of issues related to the efficiency of land use of various economic purposes by European land users as the main basis of their economic activity. Analysis of the state of land use and the experience of EU countries can serve as a vector of efficient and rational land use and be a guide for the organization of effective land policy with further integration into the European Economic Area.

Analysis of recent research and publications. The works of domestic and foreign scientists are devoted to the problems of land use potential in the conditions of globalization. Thus, the studies of economists Zaits V., Dankevych V., Dankevych E. are devoted to the study of the impact of globalization of the economy on the formation of land relations in agriculture $[2 ; 3]$. Problems of land acquisition in the context of globalization are given in the works of foreign scientists: Borras S., Franco J., Brautigam D., Schutter O., Hurni K., Spoor M. and many others [4, 5, 6, 11]. Despite the rather significant scientific achievements of domestic and foreign scientists on land use, and especially agricultural land, this issue has many problems that require additional research.

The aim of the study. Instead of discovering the special features and comparative assessment of land use systems under neocolonialism. Identify the features of the formation of agricultural land use and food security in Europe.

Results of research and discussion. Today, land resources are an extremely important structural element of civilization. Global changes in the redistribution and use of land, especially in agriculture, have a number of negative consequences that lead to intensified interstate or inter-corporate struggle to limit resources and markets. In the context of globalization, the use of land resources is accompanied by excessive use of nature in agricultural and forestry production and large-scale development of industrial facilities. In countries with a high level of corruption and legal imbalances, there is an increase in the area of industrial crops, which significantly burden the 
lands of donor countries, exports of raw materials and loss of food security, complemented by agricultural inflation prices). Global processes require a clear definition of the regional redistribution of the use of natural resources, including land. According to the World Bank classifier, it is appropriate to distribute all countries in the world in terms of gross national product per capita, so income is less than 1035 dollars. - low-income economies, 1,036 - 12,535 dollars US middle-income economy and USD 12,536 High-income economies. According to this indicator, the World Bank assesses the state of the country's economy and its long-term development. The global redistribution of land resource potential is characterized by heterogeneity. There is a tendency to increase arable land in low-income countries, which are characterized by low productivity and degradation. $[2,7]$ In the global struggle of countries for limited resources, the lion's share of which is land suitable for growing agricultural products and the desire of world leaders for food security, there is a tendency to increase arable land, usually in backward economies of Africa and Latin America. The population of these countries suffers from economic interference in the land use system of international non-resident companies and states that form domestic land banks for their own food security.

Since 2008, in world practice, the purchase or long-term lease for 50 years or more, has been called "land grabbing". International investors, as well as public, semi-public or private sellers, usually operate in offshore areas. In such private-lease relations, land reform is gaining the tone of new colonial relations due to the financial and economic dependence of "investment-attractive" states. In fact, productive lands are being seized by investing in the country's economy. Acquisition or seizure of land in this way by foreign investors or large national monopolies and the concentration of private ownership of land is one of the main dangers to food and energy security of the countries to which investments come. According to the Land Matrix, as of 2020, investors (see Figure 1) in the world have absorbed about 79.5 million hectares of fertile land in developing countries. 


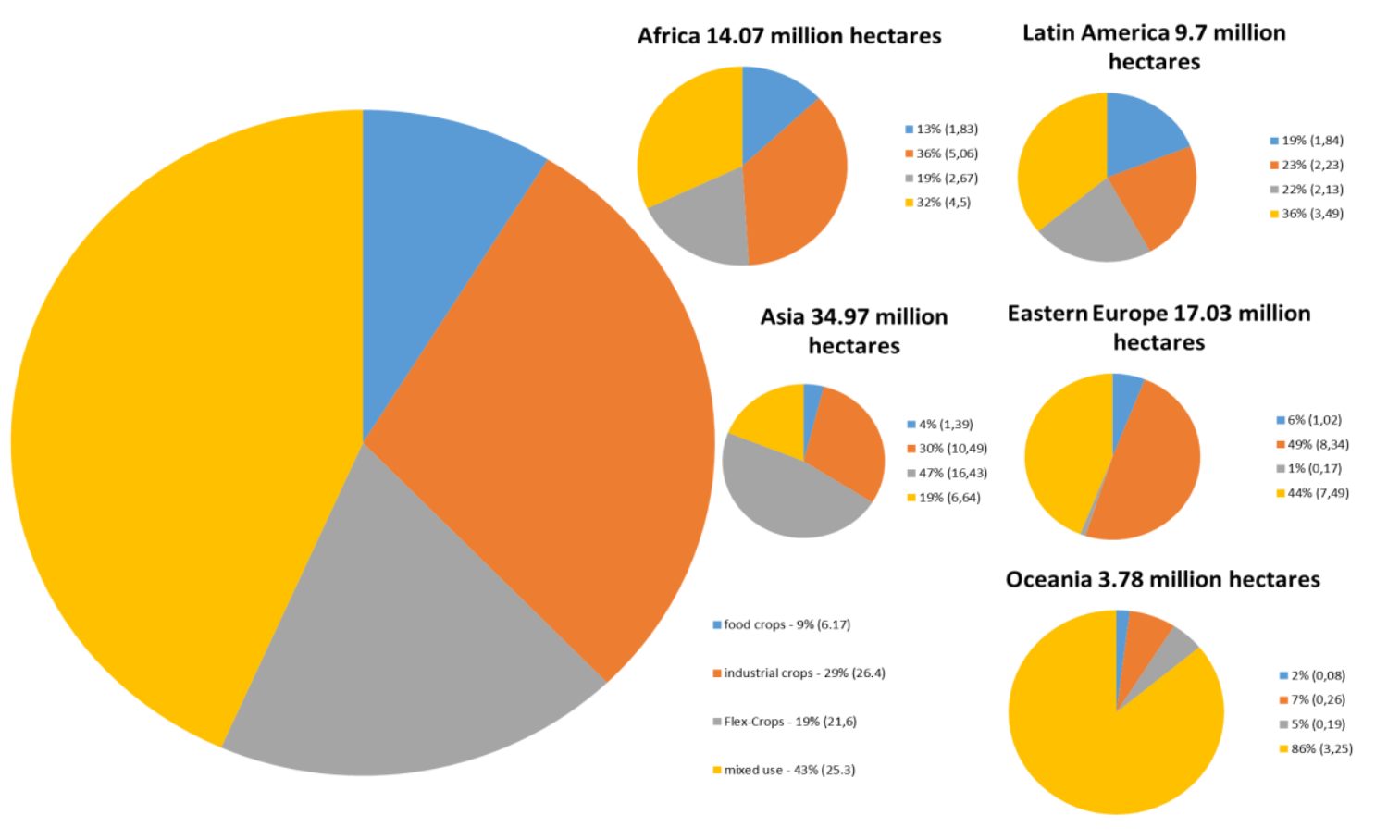

Fig. 1. World redistribution of "Land grabbing" land.

[Compiled using source 11]

The analysis shows that regions with developing economies have a high potential for increasing arable land and a favorable investment climate in the regions. According to the Land Matrix, there are no indicators of international investment in North America (USA, Canada), which indicates the presence of equity and a strategy to preserve the economic sovereignty of the state. The largest share of investments comes from Asia (61.5\% of global investors), Europe (20\% of investments) and Mon. America, and the latter does not attract foreign investment. The most attractive regions for investment are Asia, Eastern Europe, Africa, the political situation and the legislation of most countries in these regions with low levels of development (Lowincome economies) contribute to the growth of land by international corporations. The diagram (Fig. 2) shows that the aggressive investment policy of Asian and North American companies is trying to expand land tenure in other regions. Based on the principle of limited land and world resources, it would be appropriate to specify the main "investors" and investment-attractive regional economies. The most successful investors are Chinese companies that have signed contracts for the use of more than 9 million hectares of land (11.3\% of the world). 


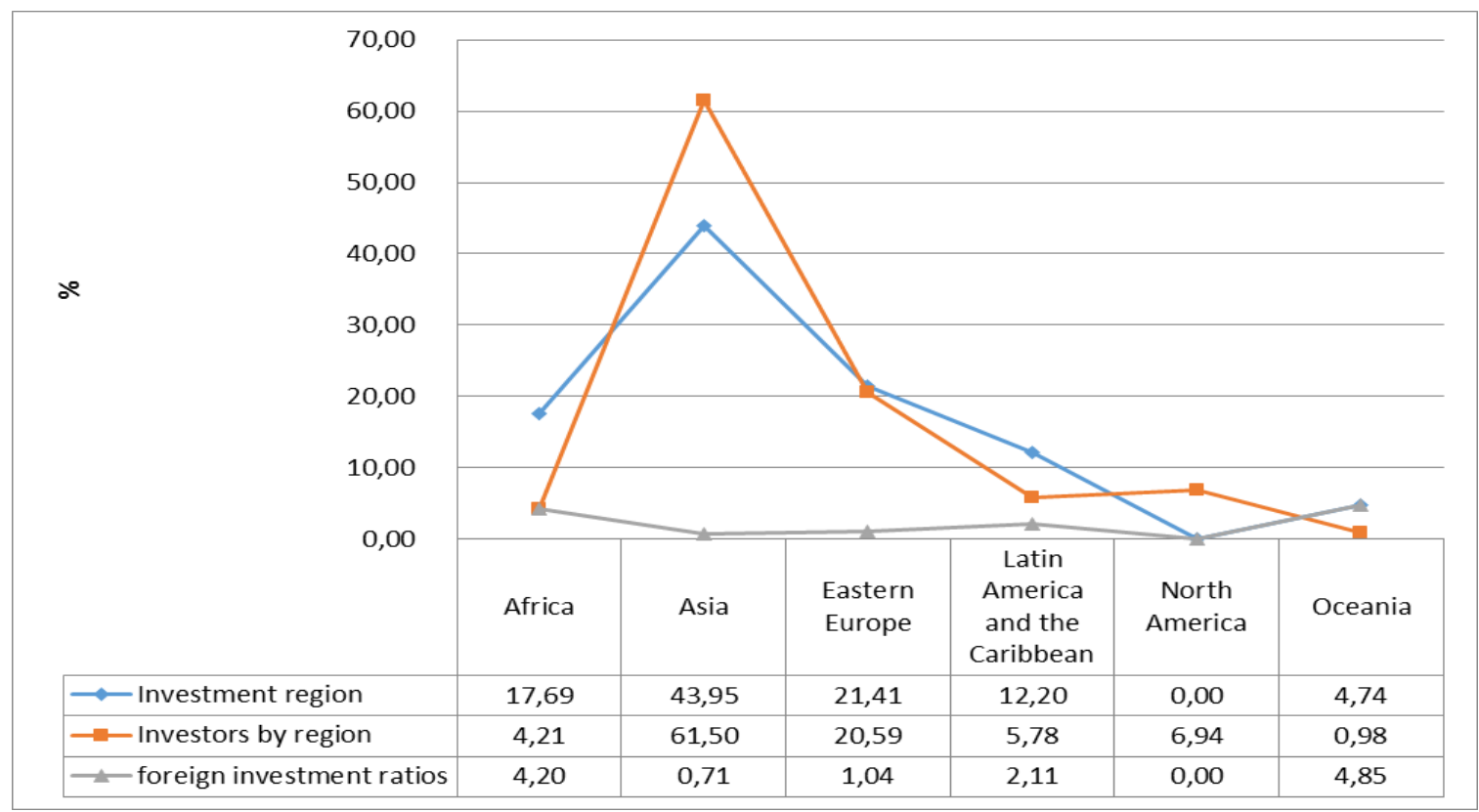

Fig.2. Investment attractiveness of regions, $\%$.

[Compiled using source 11]

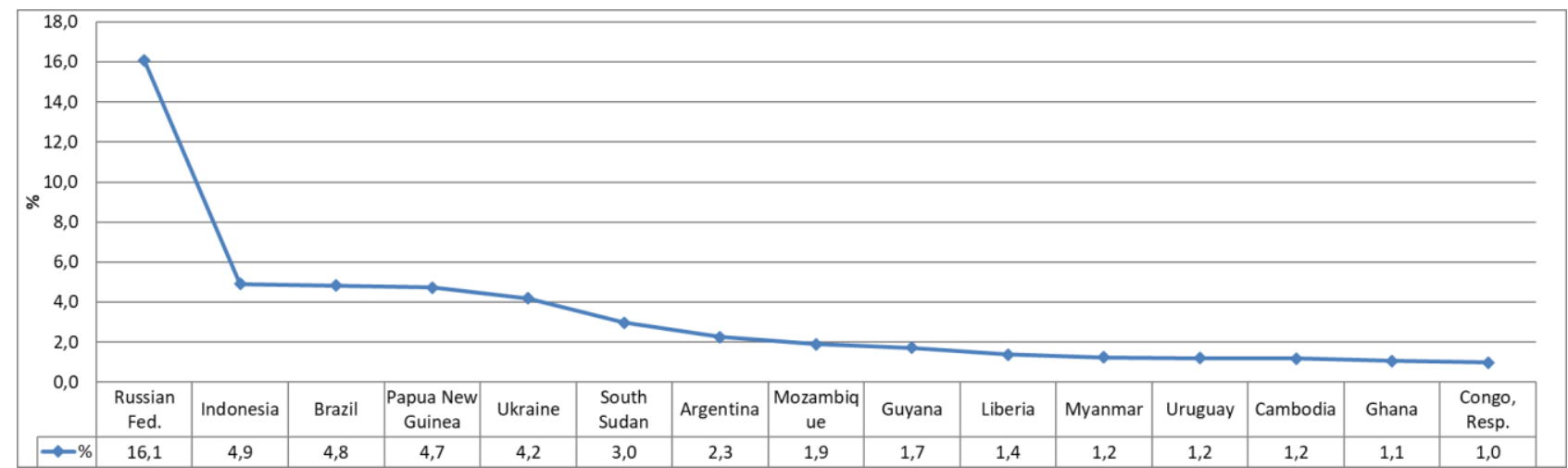

Fig.3. Area of land used by world investors, $\%$

[Compiled using source 11]

Heterogeneous redistribution of land investment among the target countries due to the favorable investment climate of the latter. The graph (Fig. 3) shows that about $16 \%$, which is 12.8 million hectares of all agreements on the target lands of the world account for the Russian Federation. In Ukraine, about 3.3 million hectares (4.2\% of the world's land grabs) are used by domestic and foreign agricultural holdings and corporations. Foreign investors control $4.2 \%$ of the territory, $7.6 \%$ of all agricultural land and 10\% of arable land in Ukraine [10]. The constant search for "free" land by international companies and the desire to invest in the economies of developing countries, give rise to new forms of land use potential. Energy facilities occupy 29\% of the total area, which allows a number of countries to form their own energy independence at the expense of donor countries. The lion's share of land is used for 
growing agricultural products, which is about $27 \%$. In this way, investor countries ensure their own food security and so on. The active participation of European countries in the global redistribution of land resources requires a more detailed study and analysis of land use. According to Land Matrix, as of 2019, companies founded by EU member states have concluded about 909 land agreements, with an area of 29 million hectares. Two-thirds of these agreements (616) cover land outside Europe with an area of 23 million hectares located on all continents except North America and Australia.

The main objectives of the agreements are the use of land for agriculture, animal husbandry, biofuel production, forestry. In such circumstances, it is quite difficult to track the final country - the investor, because the subjects are not always based in any one country, which makes such land relations too veiled. Studies "Land Concentration and Capture and the Struggle in Europe" conducted by the European Coordination Center for Farmers' Rights and Hands off the land have found that land levels are extremely high and dangerous. The greatest interest of transnational companies and foreign funds is in the lands of Bulgaria, Romania, Serbia, Moldova, Ukraine and the Russian Federation (Table 1), which have become the object of economic and financial speculation by agribusiness.

Structure of EU agricultural enterprises Table 1

\begin{tabular}{|c|c|c|c|c|c|c|c|c|}
\hline & \multicolumn{2}{|c|}{ Farms } & \multicolumn{2}{|c|}{ Agricultural areas } & \multicolumn{2}{|c|}{$\begin{array}{l}\text { Small farms (up } \\
\text { to } 5 \text { hectares) }\end{array}$} & \multicolumn{2}{|c|}{$\begin{array}{c}\text { Large farms (> } 50 \\
\text { ha) }\end{array}$} \\
\hline & $\begin{array}{l}\text { thousan } \\
\mathrm{d} \\
\text { hectares }\end{array}$ & $\begin{array}{c}\text { share of } \\
\text { total EU } \\
\text { area, \% }\end{array}$ & $\begin{array}{l}\text { per } 1000 \\
\text { hectares }\end{array}$ & $\begin{array}{c}\text { share of } \\
\text { total EU } \\
\text { area, } \%\end{array}$ & $\begin{array}{c}\text { share of } \\
\text { all } \\
\text { farms, \% }\end{array}$ & $\begin{array}{c}\text { part } \\
\text { of } \\
\text { this } \\
\text { year } \\
\text { lands } \\
, \%\end{array}$ & $\begin{array}{c}\text { share of } \\
\text { all } \\
\text { farms, } \%\end{array}$ & $\begin{array}{l}\text { share of } \\
\text { land,\% }\end{array}$ \\
\hline $\mathrm{EU}$ & 10321,2 & 0,4 & $\begin{array}{c}171288 \\
5\end{array}$ & 100,0 & 65,4 & 6,1 & 7,0 & 68,1 \\
\hline Belgium & 36,9 & 2,0 & 1354,3 & 0,8 & 13,9 & 0,9 & 25,3 & 62,2 \\
\hline Bulgaria & 202,7 & 0,3 & 4468,5 & 2,6 & 82,6 & 2,9 & 4,8 & 87,3 \\
\hline Chaska Resp. & 26,5 & 0,3 & 3453,0 & 2,0 & 18,7 & 0,3 & 27,0 & 92,5 \\
\hline Denmark & 35,1 & 2,6 & 2614,6 & 1,5 & 4,4 & 0,1 & 35,3 & 85,4 \\
\hline Germany & 264,8 & 0,2 & 15166,9 & 8,9 & 8,7 & 0,3 & 30,5 & 78,3 \\
\hline Estonia & 16,7 & 1,3 & 995,1 & 0,6 & 31,6 & 1,3 & 17,7 & 85,1 \\
\hline
\end{tabular}




\begin{tabular}{|l|c|c|c|c|c|c|c|c|} 
Ireland & 137,6 & 6,6 & 4883,7 & 2,9 & 7,4 & 0,6 & 18,0 & 51,6 \\
\hline Greece & 685,0 & 9,2 & 4553,8 & 2,7 & 77,3 & 18,5 & 0,9 & 41,4 \\
\hline Spain & 945,0 & 4,4 & 23229,8 & 13,6 & 51,6 & 4,3 & 10,8 & 70,8 \\
\hline France & 456,5 & 1,3 & 27814,2 & 16,2 & 24,3 & 0,8 & 41,3 & 86,9 \\
\hline Croatia & 134,5 & 9,8 & 1563,0 & 0,9 & 69,5 & 11,4 & 3,8 & 59,0 \\
\hline Italy & 1010,3 & 0,3 & 12098,9 & 7,1 & 58,7 & 11,4 & 4,5 & 44,0 \\
\hline Cyprus & 34,9 & 0,7 & 111,9 & 0,1 & 89,6 & 28,1 & 1,0 & 33,1 \\
\hline Latvia & 69,9 & 1,5 & 1930,9 & 1,1 & 35,2 & 2,8 & 8,8 & 67,1 \\
\hline Lithuania & 150,3 & 0,0 & 2924,6 & 1,7 & 50,0 & 6,9 & 7,2 & 63,2 \\
\hline Luxembourg & 2,0 & 4,2 & 130,7 & 0,1 & 16,2 & 0,5 & 51,8 & 88,9 \\
\hline Hungary & 430,0 & 0,1 & 4670,6 & 2,7 & 81,4 & 4,8 & 3,7 & 74,4 \\
\hline Malta & 9,3 & 0,5 & 11,2 & 0,0 & 96,6 & 78,5 & 0,0 & 0,0 \\
\hline Netherlands & 55,7 & 1,3 & 1796,3 & 1,0 & 20,2 & 1,3 & 21,5 & 57,5 \\
\hline Austria & 132,5 & 13,7 & 2669,8 & 1,6 & 31,0 & 3,8 & 8,5 & 39,1 \\
\hline Poland & 1410,7 & 2,5 & 14405,7 & 8,4 & 54,3 & 13,2 & 2,4 & 31,6 \\
\hline Portugal & 259,0 & 33,2 & 3641,7 & 2,1 & 71,5 & 9,1 & 4,2 & 66,9 \\
\hline Romania & 3422,0 & 0,7 & 12502,5 & 7,3 & 91,8 & 28,7 & 0,5 & 51,1 \\
\hline Slovenia & 69,9 & 0,2 & 488,4 & 0,3 & 59,5 & 19,9 & 0,9 & 13,7 \\
\hline Slovakia & 25,7 & 0,5 & 1889,8 & 1,1 & 55,7 & 1,5 & 13,0 & 92,1 \\
\hline Finland & 49,7 & 0,6 & 2233,1 & 1,3 & 4,0 & 0,2 & 30,0 & 66,9 \\
\hline Sweden & 62,9 & 1,8 & 3012,6 & 1,8 & 10,5 & 0,7 & 24,7 & 76,5 \\
\hline Great Britain & 185,1 & 44044,0 & 16673,3 & 9,7 & 10,2 & 0,3 & 38,6 & 88,2 \\
\hline
\end{tabular}

The EU's common agricultural policy does not help curb the land acquisition process, but rather stimulates it by increasing subsidies for large agricultural producers. According to the European Coordination Via Campesina (ECVC), between 2000 and 2012, about 4.8 million jobs were lost to EU agriculture. In Europe, a third of small farms went bankrupt, 12 million in 2003 and 8 million in 2013, respectively. However, large farms own more and more land. Thus, in Europe, $50 \%$ of all agricultural land belongs to $3 \%$ of landowners. About $20 \%$ of EU farms receive $80 \%$ of subsidies, which makes the common policy illegitimate for small farmers and citizens in general $[8,9]$. After analyzing the obtained indicators, we can conclude that the countries have lost a corresponding percentage of economic 
sovereignty in matters of food production and redistribution of land rent. In the structure of land use in Ukraine, $4.26 \%$ of the territory is land used by international investors to meet their own needs. Analysis of Land Matrix data shows that the share of beneficiaries interested in using land outside their own country is not very homogeneous. In the structure of European land users, global players are: Great Britain $-8.8 \%$ of global and $20.41 \%$ of European agreements with a total area of almost 7 million hectares, the Russian Federation, respectively $9.5 \%$ and $35.6 \%$ with an area of 7.5 million hectares only domestic entities (about 12.7 million hectares in the country), Cyprus $2.8 \%$ and $10.3 \%$ respectively, as an offshore zone) with a number of investors, etc. (Table 2)

Structure of European land use Table 2

\begin{tabular}{|c|c|c|c|c|c|}
\hline \multirow{2}{*}{ The country is an investor } & \multirow{2}{*}{$\begin{array}{l}\text { Area of the } \\
\text { country, ha }\end{array}$} & \multicolumn{2}{|c|}{$\begin{array}{l}\text { Areas under concluded } \\
\text { agreements, ha }\end{array}$} & \multicolumn{2}{|c|}{ Land grabbing, $\%$} \\
\hline & & all & Europe & all & Europe \\
\hline Austria & 8387100 & 145224 & 125224 & 0,18 & 0,60 \\
\hline Belgium & 3052800 & 273028 & 2500 & 0,34 & 0,01 \\
\hline Bulgaria * & 11091200 & 48871 & 48871 & 0,06 & 0,23 \\
\hline B. Britain + Virgin Islands & 24482000 & 6994210 & 4279162 & 8,79 & 20,41 \\
\hline Denmark & 4309400 & 109303 & 71660 & 0,14 & 0,34 \\
\hline Estonia & 4522600 & 119905 & 119905 & 0,15 & 0,57 \\
\hline Ireland & 7027300 & 19043 & 5950 & 0,02 & 0,03 \\
\hline Spain & 50603000 & 247339 & 7313 & 0,31 & 0,03 \\
\hline Italy & 30131800 & 935760 & 47041 & 1,18 & 0,22 \\
\hline Cyprus & 925100 & 2251601 & 2172601 & 2,83 & 10,36 \\
\hline Latvia & 6458900 & 34454 & 34454 & 0,04 & 0,16 \\
\hline Lithuania* & 6530300 & 40000 & 40000 & 0,05 & 0,19 \\
\hline Luxembourg & 258600 & 846083 & 540883 & 1,06 & 2,58 \\
\hline Netherlands & 4152600 & 2441417 & 863445 & 3,07 & 4,12 \\
\hline Germany & 35705000 & 620638 & 182584 & 0,78 & 0,87 \\
\hline Poland & 31268300 & 5086 & 5086 & 0,01 & 0,02 \\
\hline Portugal & 9239100 & 649903 & 16300 & 0,82 & 0,08 \\
\hline Romania* & 23839100 & 196600 & 66600 & 0,25 & 0,32 \\
\hline Hungary & 9303000 & 11352 & 11352 & 0,01 & 0,05 \\
\hline
\end{tabular}




\begin{tabular}{|l|c|c|c|c|c|}
\hline Finland & 33814500 & 1023241 & 12000 & 1,29 & 0,06 \\
\hline France & 55159500 & 741650 & 251364 & 0,93 & 1,20 \\
\hline Croatia & 5654200 & 3000 & 3000 & 0,00 & 0,01 \\
\hline Czech Republic & 7886600 & 6100 & 6100 & 0,01 & 0,03 \\
\hline Sweden & 44996400 & 410287 & 341093 & 0,52 & 1,63 \\
\hline Ukraine* & 60354900 & 307414 & 307414 & 0,39 & 1,47 \\
\hline RF* & 1709824600 & 7546257 & 7494557 & 9,48 & 35,75 \\
\hline Moldova* & 3384600 & 1400 & 1400 & 0,00 & 0,01 \\
\hline Norway & 38520700 & 463964 & 18000 & 0,58 & 0,09 \\
\hline Switzerland & 4128500 & 4091398 & 3868871 & 5,14 & 18,46 \\
\hline Serbia* & 8836100 & 14568 & 14568 & 0,02 & 0,07 \\
\hline Iceland & 10300000 & 270 & 0 & 0,00 & 0,00 \\
\hline Liechtenstein & 16000 & 123635 & 1700 & 0,16 & 0,01 \\
\hline
\end{tabular}

*Taking into account domestic investment. Author's development according to Land Matrix

A detailed analysis shows that most developed countries try to delegate the economic and financial levers of land use management to developing countries, in fact beyond their own geographical borders.

Conclusions. The favorable political and economic climate of the target countries (Africa, Latin America, Asia and Eastern Europe) contributes to the formation of large foreign latifundia, whose activities are aimed at satisfying their own interests. The loss of agricultural land by states, and most land grabs of land involved in agricultural production, puts their own producer, especially the farmer, at risk and undermines national food security. In the context of economic globalization, risks in land use have begun to manifest themselves in all regions of the world with renewed vigor. Large areas of land are threatened by a significant reduction in production capacity due to a number of negative factors. The globalization of the use of land resources of a number of countries leads to the formation of new zones of economic influence by global corporations. Acquisition of ownership or lease by foreign beneficiaries forms new economic borders between countries and deprives the latter of economic and food sovereignty.

\section{Referens}


1. Vulf, Erik R. Europe and peoples without history / Translated from English I. Poshyvaila.- K.: «KM Academy» Publishing House, 2004.- 535 s.

2. Dankevych V. Ye., Dankevych Ye. M., Sheheda O. V. The impact of economic globalization on the formation of land relations in agriculture. Problems of the economy. 2019. № 2 (40). S. 5-14

3. Zaiats V. M. Development of the market of agricultural lands: monograph. Kiev: NNTs IAE, 2011. $390 \mathrm{~s}$

4. Brautigam, D. (2015). Will Africa Feed China? Oxford: Oxford University Press.

5. Borras, S., Franco, J., Gómez, S., Kay, C. and Spoor, M., 'Land grabbing in Latin America and the Caribbean', The Journal of Peasant Studies, 39:3-4, 2012, p. 851

6. De Schutter, O. (2011). "How not to think of land-grabbing: three critiques of large-scale investments in farmland”. Journal of Peasant Studies 38(2): 249-279.

7. Doing Business 2020. World Bank. : veb-sait. URL: http:// openknowledge. worldbank.org/ bitstream/ handle/10986/32436/ 9781464814402.pdf (date of application: 12.10.2020).

8. EUROPEAN COORDINATION VIA CAMPESINA. website. URL: http:// Www.eurovia.org/wp-content/uploads/2020/09/2020-09-03-EN-ECVCcontribution-EU-Vision-Rural-Areas.pdf (date of application: 10.10.2020)

9. Eurostat KI newsrelease105/2018 - 28 June 2018 Farm structure survey 2016

10. LAND MATRIX COUNTRY PROFILE AUGUST 2020

11. Spoor, M. and Visser, O. (2011) "Land grabbing in former Soviet Eurasia". Retrieved from

http://www.future-agricultures.org/papers-andpresentations/ presentations1/1385-max-spoor-and-oane-visser/file

Чумаченко О.М., Кривов'яз С.В., Жук О.П. 
СВРОПЕЙСЬКИЙ

\section{РЕСУРСНОГО ПОТЕНЦАЛУ В УМОВАХ ГЛОБАЛІЗАЦӤ.}

У статті проведено аналіз використання земельно-ресурсного потенщіалу країн в умовах глобалізації. Визначено інвестиційно привабливі регіони, сочіально-економічні та політичні умови яких сприяють захопленню земель $з$ боку іноземних інвесторів. Обтрунтовано джерела продовольчої безпеки крайн із розвиненими економіками. Визначені особливості формування земельногоресурсного простору європейських крайн-неоколоніалістів. Однією із найважливіших історичних подій у політичному та сочіально-економічному вимірах світу став колоніалізм, пов'язаний з розвитком капіталізму. У книзі, Ерік Вульф, «Европа та люди без історії», детально описує світове розширення кордонів європейських держав з метою контролю як людських, так і природних ресурсів, а також для розширення світового розвитку держав та просування християнства [1]. Свропейський колоніалізм став ранньою формою глобалізації, щуо формувало більшість нинішніх політичних кордонів світу. Таким способом транспортувалися технологї̈, продукти харчування та ідеї ,що базувалися в межах краӥн-колоніалістів - Великобританії, Іспанії, Франиії, Португалії та Нідерландів тощо. Головною метою виступають можливості щодо використання обмежених ресурсів країни-колоній та отримання прибутку. Такий підхід називається неоколоніалізмом (корпоративний колоніалізм), як і класичний європейський колоніалізм на меті має всебічну експлуатащію природних ресурсів, робочої сили та ринків для отримання надприбутків.

Ключові слова: територія, землекористування, захоплення земель, продовольча безпека, сільськогосподарські землі, угіддя.

Чумаченко А.М., Кривовяз Е.В., Жук О.П.

ЕВРОПЕЙСКИЙ ОПЫТ ФОРМИРОВАНИЯ ЗЕМЕЛЬНОРЕСУРСНОГО ПОТЕНЦИАЛА В УСЛОВИЯХ ГЛОБАЛИЗАЦИИ.

В статье проведен анализ использования земельно-ресурсного потенциила стран в условиях глобализации. Определены инвестиционно привлекательные 
регионы, сочцильно-экономические $u$ политические условия которых способствуют захвату земель со стороны иностранных инвесторов. Обоснованно источники продовольственной безопасности стран с развитыли экономиками. Определень особенности формирования земельно-ресурсного пространства европейских стран - неоколониалистов. Одним из важнейших исторических событий в политической и соцчиально-экономическом жизни мира стал колониализм, связанный с развитием капитализма. Книга, Эрика Вульфа, «Европа и люди без истории», подробно описывает мировое расширение границ европейских государств с ичелью контроля как человеческих, так и природных ресурсов, а также для расширения мирового развития государств и продвижения христианства [1]. Европейский колониализм стал ранней формой глобализации и сформировал большинство нынешних политических грании мира. Таким образом передавались технологии, продукть питания, идеи, которые базировались в пределах стран-колонизаторов: Великобритании, Испании, Француии, Португалии и Нидерландов. В таких условиях главной цุелью выступают возможности использования ограниченных ресурсов страны-колоний и получения прибыли. Такой подход называется неоколониализмом (корпоративный колониализм), как и классический европейский колониализм цуелью имеет всестороннюю эксплуатацию природных ресурсов, рабочей сильл и рынков для получения сверхприбылей.

Ключевые слова: территория, землепользования, захват земель, продовольственная безопасность, сельскохозяйственные земли, угодья. 
